\title{
Neuroimaging at Term Equivalent Age: Is There Value for the Preterm Infant? A Narrative Summary
}

\author{
Rudaina Banihani * ${ }^{\mathbb{D}}$, Judy Seesahai, Elizabeth Asztalos and Paige Terrien Church \\ Newborn \& Developmental Paediatrics, Sunnybrook Health Science Centre, 2075 Bayview Ave, \\ The University of Toronto, Toronto, ON M4N 3M5, Canada; judy.seesahai@sunnybrook.ca (J.S.); \\ elizabeth.asztalos@sunnybrook.ca (E.A.); paige.church@sunnybrook.ca (P.T.C.) \\ * Correspondence: rudaina.banihani@sunnybrook.ca; Tel.: +416-480-6100 (ext. 88253)
}

check for updates

Citation: Banihani, R.; Seesahai, J.;

Asztalos, E.; Terrien Church, P.

Neuroimaging at Term Equivalent Age: Is There Value for the Preterm Infant? A Narrative Summary. Children 2021, 8, 227. https://doi.org/ 10.3390 /children 8030227

Academic Editor: Mark Dzietko

Received: 21 January 2021

Accepted: 10 March 2021

Published: 16 March 2021

Publisher's Note: MDPI stays neutral with regard to jurisdictional claims in published maps and institutional affiliations.

Copyright: (c) 2021 by the authors. Licensee MDPI, Basel, Switzerland. This article is an open access article distributed under the terms and conditions of the Creative Commons Attribution (CC BY) license (https:// creativecommons.org/licenses/by/ $4.0 /)$.

\begin{abstract}
Advances in neuroimaging of the preterm infant have enhanced the ability to detect brain injury. This added information has been a blessing and a curse. Neuroimaging, particularly with magnetic resonance imaging, has provided greater insight into the patterns of injury and specific vulnerabilities. It has also provided a better understanding of the microscopic and functional impacts of subtle and significant injuries. While the ability to detect injury is important and irresistible, the evidence for how these injuries link to specific long-term outcomes is less clear. In addition, the impact on parents can be profound. This narrative summary will review the history and current state of brain imaging, focusing on magnetic resonance imaging in the preterm population and the current state of the evidence for how these patterns relate to long-term outcomes.
\end{abstract}

Keywords: neonates; magnetic resonance imaging; neuroimaging; cranial ultrasound; neurodevelopmental; premature infants; parental perception

\section{Introduction}

Advances in perinatal and neonatal care have improved survival rates for very preterm infants (born $\leq 30$ weeks gestation age GA) [1-3]. The developing preterm brain is uniquely vulnerable to hypoxic, hemorrhagic, and/or inflammatory injury. The two most frequently reported findings include intracranial hemorrhage and white matter abnormalities (WMA) $[4,5]$. Both are associated with substantial neurodevelopmental challenges, including cerebral palsy (CP) and mild motor dysfunction, neurosensory impairment, cognitive, language, as well as behavioural disorders such as attention-deficit-hyperactivity disorder (ADHD) and autism spectrum disorder (ASD) [6-8]. These outcomes have associated impacts on individuals, families, and society [9]. Early identification and the provision of targeted interventions are essential to the infants' and their families' quality of life [10-13].

As neuroimaging has evolved, the identification of brain injuries in the preterm population has become more sophisticated, demonstrating a complex and diverse spectrum of brain injury [14]. Ironically, this diverse pattern of presentations on neuroimaging has limited the prediction of outcome [15]. The univariate nature of imaging is one of the most significant limiting factors for its prognostic efficacy. Images alone cannot account for the complex nature of perinatal and neonatal brain injuries with a potpourri of extracranial factors correlated to the developmental outcome, including nutrition, social and economic factors, and access to early identification and targeted interventions [16]. Additionally, the dynamic nature of brain development and potential injury in this unique population underlies the significance of the timing of imaging. These collective factors contribute to the widely variable sensitivity and specificity of neuroimaging in predicting later development.

This narrative summary will review the history and current state of brain imaging, focusing on cranial ultrasound and magnetic resonance imaging (MRI) in the preterm population to predict later neurodevelopmental outcomes. The updated guidelines from 
the American Academy of Neurology (AAN) [17], the American Academy of Pediatrics (AAP), and the Canadian Pediatric Society (CPS) $[5,18]$ regarding MRI screening in this population will also be summarized.

\section{History of Neuroimaging and Patterns of Brain Injury in the Preterm Population}

Neuroimaging emerged as a diagnostic tool in the mid-1970s with cranial ultrasonography (US) to assess intracranial hemorrhage in neonates [19]. In 1978, Dr. Volpe indicated that one of the primary goals of neuroimaging in preterm infants was to "identify those with a hopeless prognosis" [20]. Neuroimaging offered additional depth and detail previously unavailable.

Over the last 40 years, cranial US, with its ease of use, has become the primary neuroimaging modality to evaluate intracranial pathology in preterm infants and predict long-term neurodevelopmental outcomes. It is cost-efficient, readily available, and easily performed at the bedside. In addition, it offers an imaging modality free of exposure to ionizing radiation as opposed to computerized tomography (CT) scans [21]. A routine imaging schedule for preterm infants less than 32 weeks gestational age (GA) with the cranial US is now followed in neonatal intensive care units (NICU) $[5,18]$. In order to standardize the descriptions of injury documented on the cranial US, grading systems were developed by Papile et al. [22] Table 1 and Volpe [23], with that from Papile being the most widely used to date.

Table 1. Germinal matrix hemorrhage and intraventricular hemorrhage (GMH-IVH) grading system by Papile et al. [22].

\begin{tabular}{|c|c|}
\hline Grade & Description in the Parasagittal View \\
\hline I & $\begin{array}{c}\text { Germinal matrix hemorrhage (GMH) only or germinal matrix hemorrhage plus intraventricular } \\
\text { hemorrhage less than } 10 \% \text { of the ventricular area }\end{array}$ \\
\hline II & GMH and intraventricular hemorrhage; 10 to $50 \%$ of the ventricular area \\
\hline III & $\begin{array}{l}\text { GMH and intraventricular hemorrhage involving more than } 50 \% \text { of the ventricular area; lateral } \\
\text { ventricles are usually distended }\end{array}$ \\
\hline IV & $\begin{array}{l}\text { Hemorrhagic infarction in periventricular white matter ipsilateral to intraventricular hemorrhage } \\
\text { (also called periventricular hemorrhagic infarction [PVHI]) }\end{array}$ \\
\hline
\end{tabular}

Note. The description is in part based on the percentage (\%) volume of the lateral ventricle fill by blood.

One key change from Volpe, however, has been the revision of the finding once referred to as a Grade IV IVH by Papile [22] to that which is now referred to as a periventricular hemorrhage (PVH) [23]. A PVH infarction (PVHI) is attributed to impaired venous drainage of the white matter's medullary veins following a GMH-IVH [24-26]. It is viewed as a separate finding from IVH and can be found with any injury grade. In addition to hemorrhagic injuries, cranial US also provided visualization of ischemic injury of the cortical white matter, referred to as periventricular leukomalacia (PVL) [26-28]. Expansion of the intracranial windows has also allowed greater visualization of the cerebellum, now recognized as having the potential for hemorrhagic or ischemic injury and its own consequences for neurodevelopmental outcomes [29].

Imaging the entire brain was once performed using computer tomography (CT), but this has shifted to cranial US and MRI, which offer either more specific detail and avoid ionizing radiation [30]. One of the earliest studies using CT scans in preterm was in 1983 to predict long-term outcomes in the preterm population. The authors described the association of major developmental and neuromotor handicaps with the findings of more severe (grade III and IV) IVH on CT scans performed between 3 and 10 days of age [31]. In 1994, infants with HIE were receiving at least one CT scan during their initial hospitalization as it was deemed more efficient, despite concerns regarding radiation exposure, the ease of cranial US, and the superiority of MR imaging in this population [32]. CT can identify severe deep gray matter lesions with similar sensitivity to MRI, and injuries to the thalami and basal ganglia on CT have been associated with death or significant 
neurologic sequelae at 18 months of life [33]. However, CT does not identify white matter cortical injury or cerebellar injury as effectively as MRI [34,35]. CT has been used to assess for calcifications, hemorrhage, brain injury, and edema secondary to hypoxia-ischemia, venous sinus thrombosis, masses, and structural abnormalities, but this modality is now primarily supplanted by MRI due to the ionizing radiation required for imaging. Except for emergencies, CT scans are now generally avoided for newborn imaging [5]. Therefore, $\mathrm{CT}$ is no longer considered a part of routine imaging techniques of the preterm brain. The main benefit of CT remains its rapid acquisition time, obviating the need for sedation of the infant and better visualization of superficial structures over the cranial US.

In 1985, MRI emerged as an additional safe imaging option for neonatal brains [36], initially describing findings in neonatal encephalopathy (NE) [37]. Benefits associated with MRI included more detailed images and no ionizing radiation [38-41]. Since those early studies, MRI technology has demonstrated better sensitivity and specificity for detecting brain injury in neonates, particularly in the thalami and basal ganglia [42] The use of MRI extended into the preterm cohort as well, demonstrating a broader sense of the extent of white matter injury or white matter abnormality (WMA) [43]. Types of WMA include ventriculomegaly, decreased white matter volume, increasing intensity of white matter signal, and evidence of decreased myelination [44-47]. The remainder of the MRI abnormalities described in preterm infants are more focal in nature, most commonly being punctate lesions [48-50], representing clusters of activated microglia. Although classic cystic PVL is the WMA that has been the most thoroughly investigated in preterm infants, it represents only about $4 \%$ of the abnormalities seen on term equivalent age (TEA) MRI [48,49].

Another significant advantage of MRI is the detailed images of the posterior fossa and detection of cerebellar hemorrhage $(\mathrm{CBH})$, ranging from small punctate lesions, focal unilateral bleeds, and massive bleeds involving both hemispheres and including the vermis [51,52]. While few IVH are missed by routine cranial US, $\mathrm{CBH}$ is identified more readily on MRI versus cranial US $[44,47,53]$. A recent study showed CBH on MRI in $10 \%$ of the cohort, whereas only $2 \%$ had hemorrhage detected on the cranial US [54,55]. A grading system for $\mathrm{CBH}$ has been developed based on the lesion(s) location and extent of the bleeding as crucial variables concerning the neurodevelopmental outcomes [47,52,56,57].

Practical considerations include the cost of MRI estimated at GBP 315 (CAD 550) per patient $[38,58]$. There are also technical challenges, with MRI not being available in most NICUs at the bedside, requiring transportation to the imaging suite. They are also more time consuming to obtain and more sensitive to motion artifacts, thereby requiring sedation. Sedation and neonatal transport are often imperative, requiring personnel with these competencies [59-63].

In addition, there are an array of contraindications to MRI, including implanted or attached electronic and ferromagnetic devices (e.g., pacemakers, ferrous aneurysm clips). All personnel, monitoring and support equipment must be safe for the magnet. Yet, most resuscitation equipment is not magnet-safe and cannot be brought into the MRI scanning room, limiting the modality to those that are clinically stable or for whom there is no other acceptable option. $[39,64]$. Lastly, accurate neonatal MRI readings require expertise by knowledgeable pediatric neuroradiologists. In particular, the ability to detect mild and moderate degrees of injury on MRI may need sophisticated scanning sequences as well as additional proficiency in the analysis of these results [65-67].

\section{Correlation of Neuroimaging Findings with Neurodevelopmental Outcomes}

These advances in the development and utilization of cranial US and MRI have enhanced brain injury detection in preterm infants and improved the understanding of the links between brain injury and neurodevelopmental outcomes. In particular, neuroimaging is able to identify preterm infants with significant brain injury who are at-risk for neurodevelopmental challenges $[15,44,68]$. This section will review the specific imaging technique and evidence around the associated long-term outcome. 


\subsection{Cranial US}

Cranial US remains the NICU's primary imaging tool worldwide $[5,18,56]$. This is related to its ease of use and cost-efficiency. It has also been the most commonly used neuroimaging modality for predicting long-term outcomes [69].

The correlation between IVH diagnosed by the cranial US in the first one to two weeks of life and later developmental outcomes were the focus of early studies. One of the earliest outcome studies in 1989 reported that grade II or higher cerebroventricular hemorrhage $(\mathrm{CVH})$ was $79 \%$ sensitive for the development of $\mathrm{CP}$ and $70 \%$ sensitive for intellectual challenges by two years of life [70]. Today, however, $\mathrm{CP}^{\prime}$ s risk due to isolated IVH has been much lower, mostly due to care and management changes in the NICU [71,72]. Subsequent recent studies, including extremely low gestational age neonates (ELGANs), have estimated the risk rate of CP in isolated IVH to be between 9 and $17 \%$, compared to $4-6 \%$ in infants with normal cranial US results $[73,74]$. The finding of PVHI (described originally as grade IV IVH) has been associated with more significant motor and cognitive impairments [75-80]. PVL was reported to be the strongest sonographic predictor of abnormal motor outcomes and $\mathrm{CP}$ in preterm infants [81-85].

Late cranial US findings (35 to 42 weeks postmenstrual age) associated with cognitive delay and/or psychomotor delay include moderate/severe ventriculomegaly, echolucencies and echodensities, severe IVH (grade III or higher), and periventricular hemorrhage $[15,69,79,86]$.

The predictive value of cranial US remains low despite technological advances and high-frequency probes. The ELGAN study found $43 \%$ of infants who develop CP had no significant IVH, WMA, or ventriculomegaly on the cranial US, and $6 \%$ had normal findings on the cranial US [74]. Table 2 presents a review of some of the evidence around the cranial US and long-term outcome. 
Table 2. The predictive value of the cranial ultrasound in preterm infants.

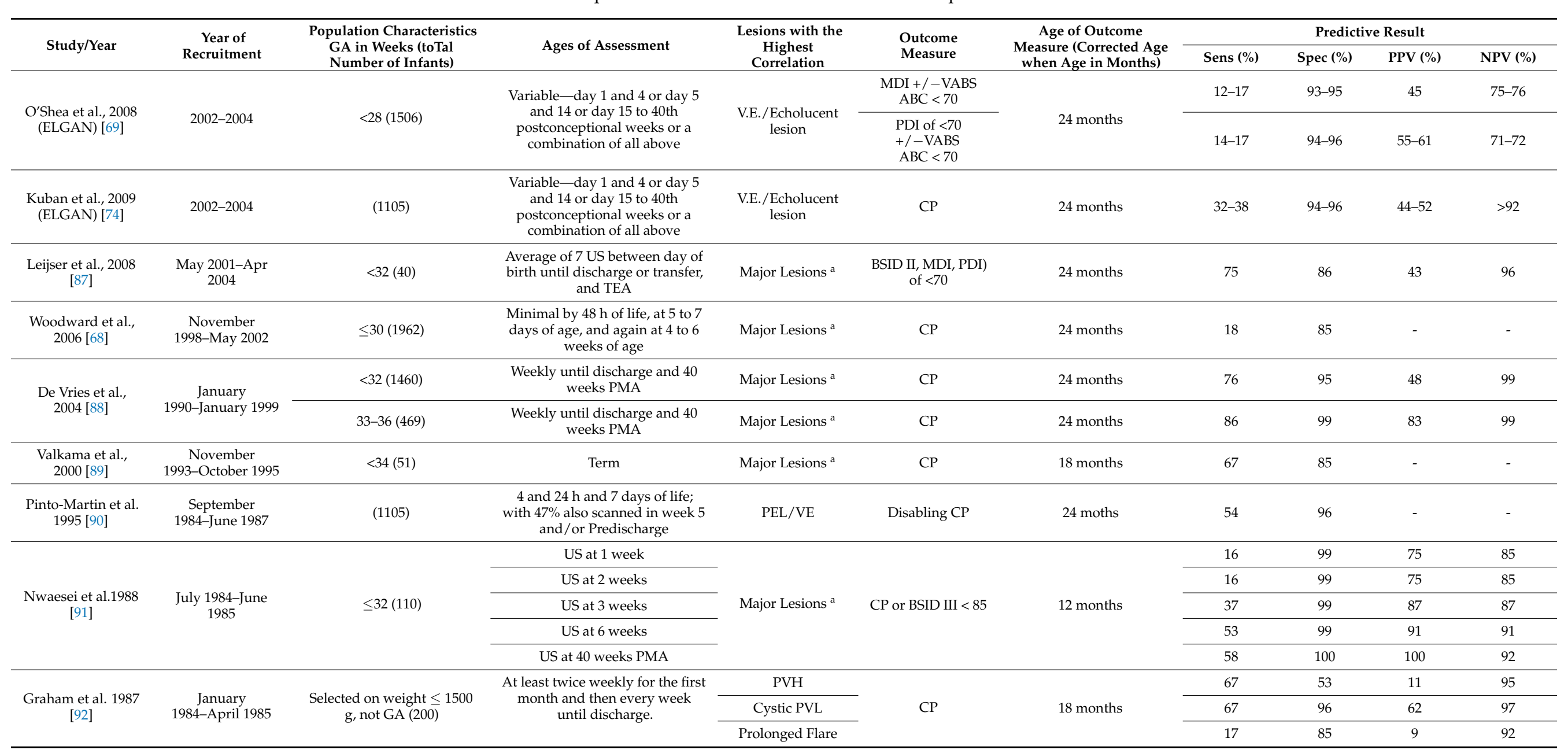

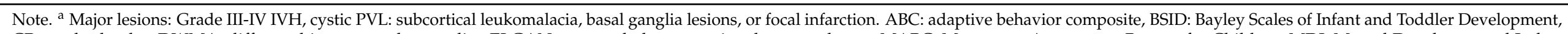

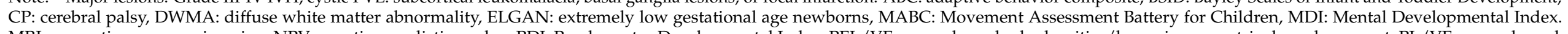

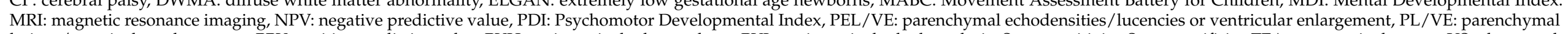

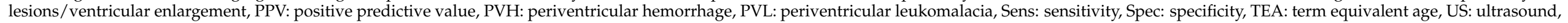
weeks: weeks, VABS: Vineland Adaptive Behavior Scales, WMA: white matter abnormalities. 


\subsection{Magnetic Resonance Imaging}

In contrast, MRI has demonstrated more sensitive and specific imaging information about central nervous system (CNS) abnormalities. As a result, MRI is increasingly being used in many NICU settings to identify cerebral WMA in preterm infants' brains at TEA [93-95].

One of the first extensive studies to examine the link between findings on neuroimaging and neurodevelopmental outcomes was by Woodward et al. [68], which demonstrated improved MRI sensitivity over the cranial US in predicting a range of neurodevelopmental challenges. The sensitivity associated with moderate-to-severe WMA on MRI for predicting cognitive delay at two years was $41 \%$, and $65 \%$ for severe motor delay or $\mathrm{CP}$, respectively. Subsequent studies (see Table 3) have demonstrated a correlation between neurodevelopmental outcome and either grossly abnormal or normal TEA MRI scans $[4,15,44,46,68,96,97]$. For those extremely preterm infants (GA $<28$ weeks) with a normal TEA cranial US, studies have demonstrated that there is a low likelihood of finding moderate or severe white matter or gray matter abnormalities on TEA MRI [98-100]. As a complement to the cranial US, TEA MRI has emerged to improve prognostic information and inform current clinical and future supportive care [101]. Table 3 presents a review of individual studies on MRI and their associated long-term outcome.

Table 3. The predictive value of the MRI at TEA in preterm infants.

\begin{tabular}{|c|c|c|c|c|c|c|c|c|c|}
\hline \multirow[b]{2}{*}{ Study/Year } & \multirow[b]{2}{*}{$\begin{array}{c}\text { Year of } \\
\text { Recruitment }\end{array}$} & \multirow{2}{*}{$\begin{array}{c}\text { Population } \\
\text { Characteristics GA in } \\
\text { Weeks (Total Number } \\
\text { of Infants) }\end{array}$} & \multirow{2}{*}{$\begin{array}{l}\text { Lesion with } \\
\text { Highest } \\
\text { Correlation }\end{array}$} & \multirow[b]{2}{*}{$\begin{array}{l}\text { Outcome } \\
\text { Measure }\end{array}$} & \multirow{2}{*}{$\begin{array}{l}\text { Age of Outcomes } \\
\text { Measures (Corrected } \\
\text { Age when Age } \\
\text { in Months) }\end{array}$} & \multicolumn{4}{|c|}{ Predictive Result } \\
\hline & & & & & & $\begin{array}{c}\text { Sens } \\
(\%)\end{array}$ & $\begin{array}{c}\text { Spec } \\
(\%)\end{array}$ & $\begin{array}{l}\text { PPV } \\
(\%)\end{array}$ & $\begin{array}{l}\text { NPV } \\
(\%)\end{array}$ \\
\hline \multirow{2}{*}{$\begin{array}{l}\text { Parikh et al., } \\
2020 \text { [102] }\end{array}$} & \multirow{2}{*}{$\begin{array}{l}\text { November } \\
2014 \text { and } \\
\text { march } 2016\end{array}$} & \multirow{2}{*}{$\leq 31(98)$} & \multirow{2}{*}{$\begin{array}{l}\text { Moderate-to- } \\
\text { severe } \\
\text { DWMA }\end{array}$} & $\begin{array}{c}\text { BSID III } \\
\text { Cognitive }<70\end{array}$ & \multirow{2}{*}{24 months } & 100 & 95.7 & \multirow{2}{*}{-} & \multirow{2}{*}{-} \\
\hline & & & & $\begin{array}{c}\text { BSID III } \\
\text { language }<70\end{array}$ & & 37.5 & 93.9 & & \\
\hline \multirow[b]{2}{*}{$\begin{array}{l}\text { Slaughter et al., } \\
2016 \text { [103] }\end{array}$} & \multirow[b]{2}{*}{$\begin{array}{l}\text { August } 2005 \\
\text { and } \\
\text { November } \\
2007\end{array}$} & \multirow[b]{2}{*}{$\begin{array}{l}\text { Based on the weight of } \\
\text { ELBW, not GA (122) }\end{array}$} & $\begin{array}{l}\text { Diffuse cystic } \\
\text { changes }\end{array}$ & Death or CP & \multirow[t]{2}{*}{ 18-24 months } & 33 & 94 & \multirow[t]{2}{*}{-} & \multirow[t]{2}{*}{-} \\
\hline & & & $\begin{array}{l}\text { Gyral } \\
\text { maturational } \\
\text { delay }\end{array}$ & $\begin{array}{c}\text { Death, CP, } \\
\text { BSID III < 80, } \\
\text { or sensory } \\
\text { challenges } \\
\text { (vision or } \\
\text { hearing loss) }\end{array}$ & & 33 & 97 & & \\
\hline \multirow[t]{2}{*}{$\begin{array}{c}\text { Spittle et al., } 2011 \\
\text { [104] }\end{array}$} & \multirow[t]{2}{*}{$\begin{array}{l}2001 \text { and } \\
2003\end{array}$} & \multirow{2}{*}{$\begin{array}{c}<30 \text { weeks or } \\
\text { birthweight }<1250 \mathrm{~g} \\
(227)\end{array}$} & $\begin{array}{l}\text { Moderate-to- } \\
\text { severe WMA } \\
\text { (30) }\end{array}$ & \multirow[t]{2}{*}{$\begin{array}{l}\mathrm{CP} \text { or } \mathrm{MABC}< \\
5 \text { th percentile }\end{array}$} & \multirow[t]{2}{*}{5 years } & \multirow[t]{2}{*}{-} & \multirow[t]{2}{*}{-} & 34 & 91.4 \\
\hline & & & $\begin{array}{l}\text { Any Severity } \\
\text { WMA }\end{array}$ & & & & & 92.5 & 40.7 \\
\hline \multirow[t]{2}{*}{$\begin{array}{l}\text { Woodward et al., } \\
2006 \text { [68] }\end{array}$} & \multirow[t]{2}{*}{$\begin{array}{l}\text { November } \\
\text { 1998-May } \\
2002\end{array}$} & \multirow[t]{2}{*}{$\leq 30$ (1962) } & $\begin{array}{l}\text { Moderate-to- } \\
\text { severe WMA } \\
\text { in (35) } 21 \%\end{array}$ & \multirow[t]{2}{*}{$\begin{array}{l}\text { CP or severe } \\
\text { cognitive or } \\
\text { motor delay }\end{array}$} & \multirow[t]{2}{*}{24 months } & $41-65$ & $84-85$ & \multirow[t]{2}{*}{-} & \multirow[t]{2}{*}{-} \\
\hline & & & $\begin{array}{l}\text { Any Severity } \\
\text { WMA }\end{array}$ & & & $88-94$ & $30-31$ & & \\
\hline $\begin{array}{l}\text { Valkama et al., } \\
2000 \text { [89] }\end{array}$ & $\begin{array}{l}\text { November } \\
1993- \\
\text { October } \\
1995\end{array}$ & $<4(51)$ & $\begin{array}{l}\text { Parenchymal } \\
\text { lesions: PVH, } \\
\text { PVL, or infarct } \\
\text { WMA }\end{array}$ & $\mathrm{CP}$ & 18 month & 100 & 79 & - & - \\
\hline
\end{tabular}

ABC: adaptive behavior composite, BSID: Bayley Scales of Infant and Toddler Development, CP: cerebral palsy, DWMA: diffuse white matter abnormality, ELGAN: extremely low gestational age newborns, MABC: Movement Assessment Battery for Children, MDI: Mental Developmental Index. MRI: magnetic resonance imaging, NPV: negative predictive value, PDI: Psychomotor Developmental Index, PPV: positive predictive value, PVH: periventricular hemorrhage, PVL: periventricular leukomalacia, Sens: sensitivity, Spec: specificity, TEA: term equivalent age, US: ultrasound, weeks: weeks, VABS: Vineland Adaptive Behavior Scales, WMA: white matter abnormalities.

A meta-analysis by George et al., 2018 examined data from 31 articles to evaluate the diagnostic accuracy of early MRI performed before 36 weeks postmenstrual age in relation to later motor outcomes and CP. The results demonstrate that early structural MRI had a sensitivity of $100 \%$ and specificity of $93 \%$ for the identification of children with CP [105]. These results reinforce those from Van't Hooft et al., 2015, which demonstrated a similar CP 
prediction result [106]. However, prognostic accuracy for visual and/or hearing problems, neurocognitive and/or behavioural function was poor [106].

Imaging the posterior fossa and detecting $\mathrm{CBH}$ is one of the significant advantages of MRI over cranial US [29,55]. CBH has been associated with a substantial risk of neurologic abnormalities in preterm infants [107-110]. A follow-up study of infants with CBH at seven years of age found that these children have more challenges with attention [111-113]. Disrupted cerebellar development has been linked to a future diagnosis of autism spectrum disorder (ASD) [114], and other psychiatric disorders (e.g., schizophrenia) $[115,116]$. A high incidence of nonmotor (cognitive, language, and behavior development) delay in infants with neonatal $\mathrm{CBH}$ was confirmed in a recent systematic review by Hortensius, Dijkshoorn et al., 2018 [109].

\subsection{Clinical Implications of Imaging at TEA}

There is evidence that abnormal findings on neuroimaging can aid in the prediction of the long-term neurodevelopmental outcome, but the challenge lies in that the predictive value is unclear, higher for more obvious lesions and lower for less clear findings (see Tables 2 and 3). The correlation between TEA cranial US and TEA MRI has a consistency of up to $88 \%$ for the predictive value in very preterm infants with brain injury evaluated for neurodevelopmental outcomes at two years of age [117,118]. In addition, up to $25 \%$ of preterm infants with an unremarkable exam on the cranial US may still present later in childhood with cognitive or psychomotor delays [69]. A similar dilemma applies to MRI studies, as not all children with WMA at TEA MRI had significant challenges, and profound neurologic impairment occurred in other children without WMA. Table 4 presents a review of some studies with a normal or unremarkable exam on neuroimaging (cranial US and MRI) [99]. 
Table 4. Normal neonatal imaging (Cranial US and TEA MRI) exam and neurodevelopmental outcomes in preterm infants.

\begin{tabular}{|c|c|c|c|c|c|c|c|c|c|c|c|}
\hline \multicolumn{12}{|c|}{ Cranial US. } \\
\hline \multirow{2}{*}{ Study/Year } & \multirow{2}{*}{$\begin{array}{c}\text { Year of } \\
\text { Recruitment }\end{array}$} & \multirow{2}{*}{$\begin{array}{l}\text { Population with no } \\
\text { US Abnormalities }\end{array}$} & \multirow{2}{*}{ Ages of Assessment } & \multirow{2}{*}{$\begin{array}{l}\text { Corrected Age } \\
\text { of Outcomes } \\
\text { Measures }\end{array}$} & \multicolumn{7}{|c|}{ Outcome } \\
\hline & & & & & \multicolumn{2}{|c|}{ Cognition } & СР (\%) & HI. (\%) & VI (\%) & NDI (\%) & Other (\%) \\
\hline $\begin{array}{l}\text { Hou et al., } 2020 \\
{[119]}\end{array}$ & 2005 to 2010 & $\mathrm{BW}<1250 \mathrm{~g}(n) 192$ & Serially from birth until Term & 2 years & 22.4 BSID III $<80$ & - & 2.1 & - & - & - & - \\
\hline $\begin{array}{l}\text { Munck et al., } \\
2010[120]\end{array}$ & 2001 to 2006 & $\begin{array}{l}\text { VLBW infants BW } \\
<1500 \mathrm{~g}(n) 91\end{array}$ & $\begin{array}{c}\text { Serially at } 3-5 \text { days, } 7-10 \text { days, at } 1 \\
\text { month and then monthly discharge and } \\
\text { then at term }\end{array}$ & 2 years & 2 BSID II & - & 0 & 0 & - & 2 & ID 2 \\
\hline $\begin{array}{l}\text { Kuban et al., } \\
2009 \text { (ELGAN) } \\
{[74]}\end{array}$ & 2002 to 2004 & $\begin{array}{l}<28 \text { weeks infants } \\
\text { (n) } 739\end{array}$ & $\begin{array}{l}\text { Variable - day } 1 \text { and } 4 \text { or day } 5 \text { and } 14 \\
\text { or day } 15 \text { to } 40 \text { th postconceptional } \\
\text { weeks or a combination of all above }\end{array}$ & 2 years & - & - & 6 & - & - & - & - \\
\hline $\begin{array}{l}\text { Laptook et al., } \\
2005[121]\end{array}$ & 1995 to 1999 & $\begin{array}{l}\text { GA } 26+/-2 \text { weeks } \\
\text { BW }<1000 \text { g infants } \\
\text { (n) } 1473\end{array}$ & mean age of 6 and 47 days & 18 to 22 months & 25 BSIDII & - & 9 & - & - & 29 & ID 25 \\
\hline $\begin{array}{l}\text { Adams- } \\
\text { Chapman et al., } \\
2008 \text { [122] }\end{array}$ & 1993 to 2002 & $\begin{array}{l}\text { BW 401-1000 g } \\
\text { infants }(n) 5163\end{array}$ & n.s. & 18 to 22 months & 27 BSID IIR & 17 BSID IIR & 10 & 1 & 9 & 35 & ID 27 \\
\hline $\begin{array}{l}\text { Ancel et al., } 2006 \\
\text { (EPIPAGE) [73] }\end{array}$ & 1997 & $\begin{array}{l}\text { GA } 22 \text { and } 32 \text { weeks } \\
\text { infants }(n) 1238\end{array}$ & $\begin{array}{c}1 \text { to } 3 \text { times in the first } 2 \text { weeks of life } \\
\text { and then every } 2 \text { weeks }\end{array}$ & 2 years & - & - & 4.4 & - & - & - & - \\
\hline $\begin{array}{l}\text { Patra et al., } 2006 \\
{[123]}\end{array}$ & 1992 to 2000 & $\begin{array}{l}\text { GA } 26.5 \text { weeks } \pm 1.9 \\
\text { infants }(n) 258\end{array}$ & $\begin{array}{l}\text { at least } 2 \text { in the first } 10 \text { days of life, then } \\
30 \text { days and at least } 1 \text { before discharge }\end{array}$ & 20 months & 25 BSIDII & 28 BSID-II & 3 & 2 & - & 28 & ID 25 \\
\hline $\begin{array}{l}\text { Sherlook et al., } \\
2005 \text { [124] }\end{array}$ & 1991 to 1992 & $\begin{array}{l}\text { GA }<28 \text { weeks } \mathrm{BW}< \\
1000 \mathrm{~g} \text { infants }(n) 180\end{array}$ & $\begin{array}{l}\text { At least } 1 \text { by } 1 \text { st week of life, at } 28 \text { days, } \\
\text { and prior to discharge }\end{array}$ & $\begin{array}{l}8 \text { years } \\
\text { chronological } \\
\text { age }\end{array}$ & - & - & 6.7 & - & - & - & $\begin{array}{l}\text { Low reading } 24.4 \% \\
\text { Low spelling } 19.2 \% \\
\text { Low arithmetic } 27.6 \%\end{array}$ \\
\hline $\begin{array}{l}\text { Whitaker et al. } \\
1996[125]\end{array}$ & 1984 to 1987 & $\begin{array}{l}\text { GA } 32.1 \pm 3.0 \mathrm{BW} \\
501 \text { to } 2000 \mathrm{~g} \text { infants } \\
\text { (n) } 468\end{array}$ & $\begin{array}{c}4 \text { and } 24 \mathrm{~h} \text { and } 7 \text { days of life; with } 47 \% \\
\text { also scanned in week } 5 \text { and/or } \\
\text { Predischarge }\end{array}$ & 6 years & - & - & - & - & - & - & ID1.3 \\
\hline
\end{tabular}


Table 4. Cont.

TEA MR

\begin{tabular}{|c|c|c|c|c|c|c|c|c|c|c|c|}
\hline \multirow{3}{*}{ Study/Year } & \multirow{3}{*}{$\begin{array}{c}\text { Year of } \\
\text { recruitment }\end{array}$} & \multirow{3}{*}{\multicolumn{2}{|c|}{ Population with no US abnormalities }} & \multirow{3}{*}{$\begin{array}{c}\text { Age of } \\
\text { outcomes } \\
\text { measures }\end{array}$} & \multicolumn{7}{|c|}{ Outcome } \\
\hline & & & & & \multicolumn{2}{|c|}{ Cognition } & \multirow[b]{2}{*}{$\mathrm{CP}(\%)$} & \multirow[b]{2}{*}{ HI. (\%) } & \multirow[b]{2}{*}{ VI (\%) } & \multirow[b]{2}{*}{ NDI (\%) } & \multirow[b]{2}{*}{ Other $(\%)$} \\
\hline & & & & & $\underset{(\%)}{\text { BSID }} \underset{(\%)}{\text { MDI }}<70$ & $\begin{array}{c}\text { BSID PDI }<70 \\
(\%)\end{array}$ & & & & & \\
\hline $\begin{array}{l}\text { Anderson et al., } \\
\quad 2017 \text { [97] }\end{array}$ & 2001 to 2003 & $60 \mathrm{inf}$ & ants $\mathrm{GA}<30$ weeks $\mathrm{BW}<1250 \mathrm{~g}$ & $\begin{array}{c}7 \text { years } \\
\text { corrected age }\end{array}$ & - & - & - & - & - & - & $\begin{array}{c}\text { Intelligence quotient } \\
100.2(14.7) \\
\text { Mean (SD.) } \\
\text { Motor 9.5(3.7) } \\
\text { Mean (SD.) }\end{array}$ \\
\hline $\begin{array}{l}\text { Munck et al., } \\
2010 \text { [120] }\end{array}$ & 2001 and 2006 & & 182 infants $\mathrm{BW}<1500 \mathrm{~g}$ & $\begin{array}{c}2 \text { years } \\
\text { corrected age }\end{array}$ & - & - & 2 & - & - & 2 & ID 0 \\
\hline \multirow{2}{*}{$\begin{array}{l}\text { Woodward et al., } \\
2006 \text { [68] }\end{array}$} & \multirow{2}{*}{1998 to 2002} & \multirow{2}{*}{$\mathrm{GA}<30$ weeks } & No WMA $(n) 47$ & \multirow{2}{*}{$\begin{array}{c}2 \text { years } \\
\text { corrected age }\end{array}$} & 4 & - & 2 & - & - & 15 & ID 7 \\
\hline & & & No GrMA $(n) 85$ & & - & - & 5 & - & - & 21 & 1D 10 \\
\hline
\end{tabular}

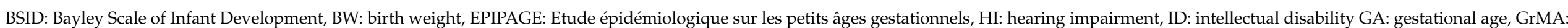

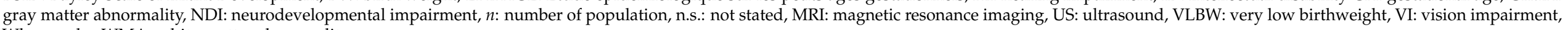
Wks: weeks, WMA: white matter abnormality. 
Term age equivalent MRI alone poorly predicted cognitive function for the individual patients at school age or later in life $[97,126]$. Adding TEA MRI to early and late cranial US also did not appear to improve the predictive ability of severe intellectual disability (ID) or significant neurodevelopmental challenges at six or seven years of age $[15,97]$.

As a result of the challenges associating findings or lack thereof with long-term outcomes, neuroimaging (cranial US and/or MRI) does not yet offer the solitary accurate predictor of long-term neurodevelopmental outcomes for individuals. Limitations may relate to the use of early $\mathrm{CP}$ as a binary variable in this population; this is a primitive metric, as many infants with IVH who demonstrate signs of CP at one to two years of life have a minimal functional impairment and an overall intelligence similar to that of controls by the time they reach school age [127]. In addition, it endorses a misperception that PVL and PVH carry universally 'poor' outcomes, which may potentially lead to alterations of care or withdrawal of care [128]. Complex decisions such as withdrawal of support necessitate a deeper investigation into models of developmental outcomes, including an emphasis on factors such as functional impacts, family impact, and quality of life; this does not yet exist [58].

\section{Effect of Diagnostic MRI on Parents and Further Follow-Up}

Preterm birth has long-lasting effects on individuals and families, and increased maternal anxiety adversely influences child development $[129,130]$. Based on data to date, neuroimaging's predictive capabilities for high-risk infants are inadequate to identify those infants that should be excluded from structured follow-up or those that should be selected for additional therapies [131-133]. Additionally, the imaging technique with the greatest predictive capacity, MRI, is performed after the acute phase of illness, making it unavailable for counselling parents on limitations of care or support withdrawal [134,135]. The main remaining benefit is that of providing parents with a risk-adjusted estimate of the developmental outcome, something that has been suggested by families and physicians to be of questionable benefit and potentially emotionally harmful $[134,136]$. Pearce and Baardsnes (2012) articulated parental perspective in the impact of neuroimaging at TEA [136]:

"We are not angry at the hospital, but knowing what we know now, we never would have consented to an MRI, because it served no purpose other than to traumatize a family that had already been through so much and affect our ability to enjoy bonding with our child."

Subsequently, parents have reported that there is a significant emotional impact associated with brain imaging during their infant's NICU admission $[58,136]$. Edwards, Redshaw et al., 2018, studied the effect of MRI on preterm infants and their families and demonstrated that maternal anxiety was reduced after receiving information from neuroimaging (cranial US and/or MRI) and slightly more after an MRI compared with the cranial US. However, this reduction was not clinically significant and did not contribute to a better health-related quality of life for the child and family [58].

While the evidence is limited [137], most parents have expressed interest in more accurate long-term prognostic information, especially from a TEA MRI, in order to properly plan post-discharge early intervention support services. Despite that, it has been reported that parent's concerns about long-term developmental outcomes and the need for information did not diminish over time or with the knowledge of assuring normal brain neuroimaging results and the baby's stable condition [137-139]. The emotional impact of having a preterm baby had a negative effect on parents' ability to retain information while in the NICU, and all had an ongoing need for reassurance beyond the hospital period [137].

In addition to the parent's perspective regarding neuroimaging in the NICU, $10 \%$ of infants will demonstrate unexpected abnormalities on TEA MRI not acquired in the perinatal period (i.e., not already diagnosed prenatally or postnatally by clinical signs or the cranial US) $[140,141]$. Incidental findings in the adult population are identified in $1-4 \%$ of brain MRIs, with up to one-third of those neoplastic. Many of the remaining findings were considered benign without the need for follow-up [142]. Contrary to adult literature, extreme preterm infants tend to have a higher rate of incidental findings (9.7\%) 
on TEA MRI requiring follow-up $[140,141]$. These incidental findings increase parental anxiety $[143,144]$. One-quarter of these findings were deemed benign (e.g., small benign venous anomalies, arachnoid cysts, corpus callosum dysgenesis, absent septum pellucidum, frontal scalp mass and a nasal septum cyst) and required no further follow-up. The remaining three-quarters required further diagnostic follow-up and/or therapeutic intervention, including cortical tubers, significant dysmorphia of the brain stem or cerebellum, and ectopic pituitary $[140,141]$. The balance between revealing silent brain abnormalities of clinical significance and discovering findings of uncertain clinical importance that result in potentially unnecessary diagnostic follow-up has led to the ongoing debate regarding the benefit and appropriateness of TEA MR imaging in this population [134,143].

\section{Moving from Research to Clinical Practice}

Despite the lack of clarity in the data as well as the cost, there have been calls to standardize the use of MRI for all former extreme preterm infants at 36-40 weeks postmenstrual age [145-148]. Magnetic resonance imaging has significant predictive value as an isolated imaging modality. However, several issues must be overcome before TEA MRI can become a standard in preterm infants. The current MRI data limit TEA MRI's clinical usefulness to predict the long-term neurodevelopmental outcome for the individual survivor accurately [44]. In addition, there are no data to support that any improved prognostic capabilities of MRI will translate into improved outcomes. Due to these limitations, performing TEA MRI for preterm infants was recently listed as one of the top five tests or treatments in newborn medicine that "cannot be adequately justified based on efficacy, safety, or cost" [134,149].

Recommendations from the American Academy of Neurology (AAN), the American Academy of Pediatrics (AAP), and the Canadian Pediatric Society (CPS) do not endorse routine MRI for preterm infants, regardless of cranial US findings $[5,17,18]$. Currently, updated guidance from both the AAP and CPS state that TEA MRI for infants should be considered mainly as a follow-up of abnormal cranial US results (e.g., severe IVH, PVL, and hydrocephalus) and following a conversation with the family regarding its limitations for estimation of long-term prognosis. [5,18,105,134,136]. A "feed and wrap" technique is preferred should MRI be pursued [18,61,150]. Brain CT is no longer considered a part of routine imaging techniques for the preterm population [18].

While MRI has not yet emerged as a solitary tool, its role as contributing important data cannot be overlooked. It is for this reason that there is a consideration for TEA MRI to be integrated into a more extensive assessment, including physical examination findings, clinical risk factors (e.g., neonatal history of bronchopulmonary dysplasia and postnatal steroids) [151,152], standardized neurological and motor assessments (e.g., General Movement Assessment (GMA) [153-155], Hammersmith Infant Neurological Examination (HINE)) [155-158] for early identification of motor challenges, mainly CP [159-163]. In a retrospective case-control study of 441Italian high-risk infants, Morgan et al., 2019 found that the combined predictive power of the three-month HINE, GMA, and neuroimaging (MRI and/or cranial US) post-term gave sensitivity and specificity values of $97.86 \%$ and 99.22\% (PPV 98.56\%, NPV 98.84\%) for detecting CP [164]. The clinical combination of these tools leads to earlier identification of CP diagnosis and facilitates earlier intervention. This will have significant implications for optimizing the child's overall function $[165,166]$, preventing secondary complications [167] and supporting the families of these children [168].

Two systematic reviews further supported a combined approach for the prediction of CP in conjunction with clinical history. Bosanquet et al., 2013 [169] looked at it in preschoolage children less than five years; one sampling mostly from preterm infants. Novak et al., 2017 [170] looked for clinical signs and CP symptoms that emerge and evolve before age two years, pooled from six systematic reviews and two evidence-based clinical guidelines. A more recent systematic review by Caesar et al., 2020 [171] evaluated the accuracy of clinical tools used at a corrected age of six months or younger to predict motor and cognitive delay at two years (not cerebral palsy) in infants born very preterm. Table 5 shows the 
result of the three recent systematic reviews of the predictive value of diagnostic tools that can identify infants at risk of long-term neurodevelopmental challenges [169-171].

Table 5. The predictive value of tools used in the early (less than six months corrected age) identification of infants at risk of long-term neurodevelopmental challenges.

\begin{tabular}{|c|c|c|c|c|c|c|c|}
\hline \multirow{2}{*}{ Study/Year } & \multirow{2}{*}{ Country } & \multirow{2}{*}{$\begin{array}{c}\text { Population } \\
\text { Characteristics }\end{array}$} & \multirow{2}{*}{ Outcomes } & \multirow{2}{*}{$\begin{array}{l}\text { Age of } \\
\text { Outcome }\end{array}$} & \multirow{2}{*}{$\begin{array}{c}\text { Diagnostic } \\
\text { Tool }\end{array}$} & \multicolumn{2}{|c|}{ Predictive Value } \\
\hline & & & & & & Sens $\%(95 \%$ CI $)$ & Spec \% (95\% CI) \\
\hline \multirow{4}{*}{$\begin{array}{l}\text { Caesar et al., } \\
2020 \text { [171] }\end{array}$} & \multirow{4}{*}{ Australia } & \multirow{4}{*}{$\begin{array}{c}\text { Ten studies } \leq \\
32 \text { weeks GA } \pm \\
\leq 1500 \text { g infants } \\
\quad(n) 992\end{array}$} & \multirow{2}{*}{$\begin{array}{c}\text { Sever motor } \\
\text { delay (not CP) }\end{array}$} & \multirow{4}{*}{2 years } & $\begin{array}{l}\text { GMA Fidgety } \\
\text { stage (AF, F-) }\end{array}$ & 70 & 85 \\
\hline & & & & & $\begin{array}{l}\text { HINE at } 3 \text { and } \\
6 \text { months }\end{array}$ & $93(68-100)$ & $100(96-100)$ \\
\hline & & & \multirow{2}{*}{$\begin{array}{c}\text { Cognitive } \\
\text { delay BSID III } \\
\leq 2 \text { SD }\end{array}$} & & $\begin{array}{l}\text { GMA Fidgety } \\
\text { stage (AF, F-) }\end{array}$ & 70 & 85 \\
\hline & & & & & $\begin{array}{l}\text { HINE at } 3 \text { and } \\
6 \text { months }\end{array}$ & Not estimable & Not estimable \\
\hline \multirow{3}{*}{$\begin{array}{l}\text { Novak et al., } \\
2017 \text { [170] }\end{array}$} & \multirow{3}{*}{ International } & \multirow{3}{*}{$\begin{array}{l}\text { Eight studies } \\
\text { All GA }\end{array}$} & \multirow{3}{*}{$\mathrm{CP}$} & \multirow{3}{*}{$<2$ years } & $\begin{array}{l}\text { TEA MRI } \\
\text { (preterm } \\
\text { infants) }\end{array}$ & $86-89$ & - \\
\hline & & & & & GMA (Prechtl) & 98 & - \\
\hline & & & & & HINE & 90 & - \\
\hline \multirow{4}{*}{$\begin{array}{l}\text { Bosanquet et al., } \\
2013 \text { [169] }\end{array}$} & \multirow{4}{*}{ Australia } & \multirow{4}{*}{$\begin{array}{l}19 \text { studies } \\
\text { 23-41 weeks }\end{array}$} & \multirow{4}{*}{$\begin{array}{c}\text { CP after } \\
2 \text { years of age }\end{array}$} & \multirow{4}{*}{$\begin{array}{l}\text { Preschool } \\
\text { children } \\
\text { (<5 year) }\end{array}$} & $\begin{array}{l}\text { TEA MRI } \\
\text { (preterm } \\
\text { infants) }\end{array}$ & $86-100$ & $89-97$ \\
\hline & & & & & Cranial US & $74(63-83)$ & $92(81-96)$ \\
\hline & & & & & GMA & $98(74-100)$ & $91(83-93)$ \\
\hline & & & & & $\begin{array}{l}\text { Neurological } \\
\text { examination }\end{array}$ & 88 (55-97) & 87 (57-97) \\
\hline
\end{tabular}

Note. CI: Confidence interval, CP: cerebral palsy, GA: gestational age, GMA: General Movements Assessment, HINE: Hammersmith Infant Neurological Examination, MRI: magnetic resonance imaging, RCT: randomized control trial, SD: standard deviation, Sens: sensitivity, Spec: specificity, TEA: term equivalent age, US: ultrasound, weeks: weeks.

This information is now being used by programs and guides screening tools, management regarding the intensity and duration of follow-up and the need for early identification and intervention. One case series suggested that this multivariate approach (risk factor assessment and MRI evidence of WMA) may help identify specific cognitive and behavioural problems in children born very preterm [172,173]. This is particularly challenging because available tools (neuroimaging and early clinical assessment) do not accurately predict longterm developmental outcomes such as cognitive, language, and behavior development in individual survivors [173], compared to predicting CP and/or motor challenges; see Tables 2 and 3 .

\section{Conclusions}

Prediction of neurodevelopmental outcomes is an essential aspect of neonatal care [13]. It allows for important counselling to offer essential information on the potential impact on a family, the child's function, and future. It also allows for early identification and targeted intervention, which has been demonstrated to improve functional outcome [170]. Currently, however, there remains a critical gap in the research surrounding neonatal neuroimaging. While neuroimaging has not yet proven to be a tool that can be used in isolation, it has been proven to add value in combination with clinical history and examination. What remains to be articulated is whether the added value of TEA MRI details and sensitivity can be harnessed more effectively to outweigh the significant barriers to use, specifically cost, technical challenges, and expertise. In addition, or perhaps expanding on that statement, consideration is needed for a shift from a simple description of images and outcomes to that which explores how these tools can be leveraged to improve outcome, rather than predicting a 'hopeless prognosis'. 
Author Contributions: Conceptualization, R.B., P.T.C., J.S. and E.A.; methodology, R.B., P.T.C., writing-original draft preparation, R.B.; writing-review and editing, J.S., P.T.C., E.A. and R.B.; Finalizing the tables, R.B. and J.S., Senior and corresponding author, R.B. All authors have read and agreed to the published version of the manuscript.

Funding: There is no external funding.

Institutional Review Board Statement: This review did not require to be reviewed by the review ethical board (REB) as it's a narrative review.

Informed Consent Statement: This review did not need patient consent as it's a review of the literatures.

Data Availability Statement: Not applicable.

Conflicts of Interest: The authors declare no conflict of interest.

\section{References}

1. Horbar, J.D.; Badger, G.J.; Carpenter, J.H.; Fanaroff, A.A.; Kilpatrick, S.; LaCorte, M.; Phibbs, R.; Soll, R.F. Trends in mortality and morbidity for very low birth weight infants, 1991-1999. Pediatrics 2002, 110, 143-151. [CrossRef]

2. Wilson-Costello, D.; Friedman, H.; Minich, N.; Siner, B.; Taylor, G.; Schluchter, M.; Hack, M. Improved neurodevelopmental outcomes for extremely low birth weight infants in 2000-2002. Pediatrics 2007, 119, 37-45. [CrossRef] [PubMed]

3. Wilson-Costello, D.; Friedman, H.; Minich, N.; Fanaroff, A.A.; Hack, M. Improved survival rates with increased neurodevelopmental disability for extremely low birth weight infants in the 1990s. Pediatrics 2005, 115, 997-1003. [CrossRef] [PubMed]

4. Woodward, L.J.; Clark, C.A.; Bora, S.; Inder, T.E. Neonatal white matter abnormalities an important predictor of neurocognitive outcome for very preterm children. PLoS ONE 2012, 7, e51879. [CrossRef]

5. Guillot, M.; Chau, V.; Lemyre, B. Routine imaging of the preterm neonatal brain. Paediatr. Child Health 2020, 25, 249-262. [CrossRef]

6. Aarnoudse-Moens, C.S.; Weisglas-Kuperus, N.; van Goudoever, J.B.; Oosterlaan, J. Meta-analysis of neurobehavioral outcomes in very preterm and/or very low birth weight children. Pediatrics 2009, 124, 717-728. [CrossRef]

7. Stahlmann, N.; Rapp, M.; Herting, E.; Thyen, U. Outcome of extremely premature infants at early school age: Health-related quality of life and neurosensory, cognitive, and behavioral outcomes in a population-based sample in northern Germany. Neuropediatrics 2009, 40, 112-119. [CrossRef]

8. Litt, J.; Taylor, H.G.; Klein, N.; Hack, M. Learning disabilities in children with very low birthweight: Prevalence, neuropsychological correlates, and educational interventions. J. Learn Disabil. 2005, 38, 130-141. [CrossRef]

9. Economic costs associated with mental retardation, cerebral palsy, hearing loss, and vision impairment-United States, 2003 MMWR Morb. Mortal. Wkly Rep. 2004, 53, 57-59.

10. Hintz, S.R.; Kendrick, D.E.; Vohr, B.R.; Poole, W.K.; Higgins, R.D. Community supports after surviving extremely low-birthweight, extremely preterm birth: Special outpatient services in early childhood. Arch. Pediatr. Adolesc Med. 2008, 162, 748-755. [CrossRef] [PubMed]

11. Litt, J.S.; Glymour, M.M.; Hauser-Cram, P.; Hehir, T.; McCormick, M.C. Early Intervention Services Improve School-age Functional Outcome Among Neonatal Intensive Care Unit Graduates. Acad. Pediatr. 2018, 18, 468-474. [CrossRef]

12. Mills, I.S.; Doyle, L.W.; Cheong, J.L.; Roberts, G. Rates of early intervention services in children born extremely preterm/extremely low birthweight. J. Paediatr. Child Health 2018, 54, 74-79. [CrossRef]

13. Spittle, A.; Orton, J.; Anderson, P.J.; Boyd, R.; Doyle, L.W. Early developmental intervention programmes provided post hospital discharge to prevent motor and cognitive impairment in preterm infants. Cochrane Database Syst. Rev. 2015, Cd005495. [CrossRef] [PubMed]

14. Volpe, J.J. Brain injury in premature infants: A complex amalgam of destructive and developmental disturbances. Lancet Neurol. 2009, 8, 110-124. [CrossRef]

15. Hintz, S.R.; Vohr, B.R.; Bann, C.M.; Taylor, H.G.; Das, A.; Gustafson, K.E.; Yolton, K.; Watson, V.E.; Lowe, J.; DeAnda, M.E.; et al. Preterm Neuroimaging and School-Age Cognitive Outcomes. Pediatrics 2018, 142. [CrossRef]

16. Walker, S.P.; Wachs, T.D.; Meeks Gardner, J.; Lozoff, B.; Wasserman, G.A.; Pollitt, E.; Carter, J.A. Child development: Risk factors for adverse outcomes in developing countries. Lancet 2007, 369, 145-157. [CrossRef]

17. Ment, L.R.; Bada, H.S.; Barnes, P.; Grant, P.E.; Hirtz, D.; Papile, L.A.; Pinto-Martin, J.; Rivkin, M.; Slovis, T.L. Practice parameter: Neuroimaging of the neonate: Report of the Quality Standards Subcommittee of the American Academy of Neurology and the Practice Committee of the Child Neurology Society. Neurology 2002, 58, 1726-1738. [CrossRef]

18. Hand, I.L.; Shellhaas, R.A.; Milla, S.S. Routine Neuroimaging of the Preterm Brain. Pediatrics 2020, 146. [CrossRef]

19. Patrick, J.T.; Fry, F.J.; Gardner, G.; Franklin, T.D.; Muller, J.; Heimburger, R.F. Ultrasound Tomography of Excised Brains: Normal and Pathological Anatomy. In Ultrasound in Medicine: Volume 4; White, D., Lyons, E.A., Eds.; Springer US: Boston, MA, USA, 1978; pp. 269-276. [CrossRef]

20. Volpe, J.J. Neonatal periventricular hemorrhage: Past, present, and future. J. Pediatr. 1978, 92, 693-696. [CrossRef] 
21. Yu, C.C. Radiation safety in the neonatal intensive care unit: Too little or too much concern? Pediatr. Neonatol. 2010, 51, 311-319. [CrossRef]

22. Papile, L.A.; Burstein, J.; Burstein, R.; Koffler, H. Incidence and evolution of subependymal and intraventricular hemorrhage: A study of infants with birth weights less than 1,500 gm. J. Pediatr. 1978, 92, 529-534. [CrossRef]

23. Volpe, J.J. Neurology of the Newborn; Elsevier: Amsterdam, The Netherlands, 2008.

24. Robinson, S. Neonatal posthemorrhagic hydrocephalus from prematurity: Pathophysiology and current treatment concepts. J. Neurosurg. Pediatr. 2012, 9, 242-258. [CrossRef]

25. Volpe, J.J. Neurologic outcome of prematurity. Arch. Neurol. 1998, 55, 297-300. [CrossRef]

26. Bassan, H. Intracranial hemorrhage in the preterm infant: Understanding it, preventing it. Clin. Perinatol. 2009, 36, 737-762. [CrossRef] [PubMed]

27. de Vries, L.S.; Eken, P.; Dubowitz, L.M. The spectrum of leukomalacia using cranial ultrasound. Behav. Brain Res. 1992, 49, 1-6. [CrossRef]

28. Jung, H.N.; Suh, S.I.; Park, A.; Kim, G.H.; Ryoo, I. Early Prediction of Periventricular Leukomalacia Using Quantitative Texture Analysis of Serial Cranial Ultrasound Scans in Very Preterm Infants. Ultrasound Med. Biol. 2019, 45, 2658-2665. [CrossRef] [PubMed]

29. Steggerda, S.J.; Leijser, L.M.; Wiggers-de Bruïne, F.T.; van der Grond, J.; Walther, F.J.; van Wezel-Meijler, G. Cerebellar injury in preterm infants: Incidence and findings on US and MR images. Radiology 2009, 252, 190-199. [CrossRef]

30. Kwon, S.H.; Vasung, L.; Ment, L.R.; Huppi, P.S. The role of neuroimaging in predicting neurodevelopmental outcomes of preterm neonates. Clin. Perinatol. 2014, 41, 257-283. [CrossRef]

31. Papile, L.-A.; Munsick-Bruno, G.; Schaefer, A. Relationship of cerebral intraventricular hemorrhage and early childhood neurologic handicaps. J. Pediatrics 1983, 103, 273-277. [CrossRef]

32. Barnette, A.R.; Horbar, J.D.; Soll, R.F.; Pfister, R.H.; Nelson, K.B.; Kenny, M.J.; Raju, T.N.K.; Bingham, P.M.; Inder, T.E. Neuroimaging in the Evaluation of Neonatal Encephalopathy. Pediatrics 2014, 133, e1508. [CrossRef]

33. Roland, E.H.; Poskitt, K.; Rodriguez, E.; Lupton, B.A.; Hill, A. Perinatal hypoxic-ischemic thalamic injury: Clinical features and neuroimaging. Ann. Neurol. 1998, 44, 161-166. [CrossRef]

34. Chau, V.; Poskitt, K.J.; Sargent, M.A.; Lupton, B.A.; Hill, A.; Roland, E.; Miller, S.P. Comparison of computer tomography and magnetic resonance imaging scans on the third day of life in term newborns with neonatal encephalopathy. Pediatrics 2009, 123, 319-326. [CrossRef] [PubMed]

35. Flodmark, O.; Becker, L.E.; Harwood-Nash, D.C.; Fitzhardinge, P.M.; Fitz, C.R.; Chuang, S.H. Correlation between computed tomography and autopsy in premature and full-term neonates that have suffered perinatal asphyxia. Radiology 1980, 137, 93-103. [CrossRef] [PubMed]

36. Dubowitz, L.M.; Bydder, G.M. Nuclear magnetic resonance imaging in the diagnosis and follow-up of neonatal cerebral injury. Clin. Perinatol. 1985, 12, 243-260. [CrossRef]

37. McArdle, C.B.; Richardson, C.J.; Hayden, C.K.; Nicholas, D.A.; Amparo, E.G. Abnormalities of the neonatal brain: MR imaging. Part II. Hypoxic-ischemic brain injury. Radiology 1987, 163, 395-403. [CrossRef]

38. Abdelhalim, A.N.; Alberico, R.A. Pediatric neuroimaging. Neurol. Clin. 2009, 27, 285-301. [CrossRef]

39. Ketonen, L.M.; Valanne, L. Neuroimaging of pediatric diseases. Semin Neurol. 2008, 28, 558-569. [CrossRef]

40. Counsell, S.J.; Edwards, A.D.; Chew, A.T.; Anjari, M.; Dyet, L.E.; Srinivasan, L.; Boardman, J.P.; Allsop, J.M.; Hajnal, J.V.; Rutherford, M.A.; et al. Specific relations between neurodevelopmental abilities and white matter microstructure in children born preterm. Brain 2008, 131, 3201-3208. [CrossRef]

41. Benavente-Fernández, I.; Lubián-López, P.S.; Zuazo-Ojeda, M.A.; Jiménez-Gómez, G.; Lechuga-Sancho, A.M. Safety of magnetic resonance imaging in preterm infants. Acta Paediatr. 2010, 99, 850-853. [CrossRef] [PubMed]

42. Rutherford, M.A.; Pennock, J.M.; Dubowitz, L.M. Cranial ultrasound and magnetic resonance imaging in hypoxic-ischaemic encephalopathy: A comparison with outcome. Dev. Med. Child Neurol. 1994, 36, 813-825. [CrossRef] [PubMed]

43. Hintz, S.R.; O'Shea, M. Neuroimaging and neurodevelopmental outcomes in preterm infants. Semin Perinatol. 2008, 32, 11-19. [CrossRef]

44. Hintz, S.R.; Barnes, P.D.; Bulas, D.; Slovis, T.L.; Finer, N.N.; Wrage, L.A.; Das, A.; Tyson, J.E.; Stevenson, D.K.; Carlo, W.A.; et al. Neuroimaging and neurodevelopmental outcome in extremely preterm infants. Pediatrics 2015, 135, e32-e42. [CrossRef]

45. Burkitt, K.; Kang, O.; Jyoti, R.; Mohamed, A.L.; Chaudhari, T. Comparison of cranial ultrasound and MRI for detecting BRAIN injury in extremely preterm infants and correlation with neurological outcomes at 1 and 3 years. Eur. J. Pediatr. 2019, 178, 1053-1061. [CrossRef] [PubMed]

46. Brown, N.C.; Inder, T.E.; Bear, M.J.; Hunt, R.W.; Anderson, P.J.; Doyle, L.W. Neurobehavior at term and white and gray matter abnormalities in very preterm infants. J. Pediatr. 2009, 155, 32-38.e3. [CrossRef] [PubMed]

47. Neubauer, V.; Djurdjevic, T.; Griesmaier, E.; Biermayr, M.; Gizewski, E.R.; Kiechl-Kohlendorfer, U. Routine Magnetic Resonance Imaging at Term-Equivalent Age Detects Brain Injury in 25\% of a Contemporary Cohort of Very Preterm Infants. PLoS ONE 2017, 12, e0169442. [CrossRef]

48. Inder, T.E.; Warfield, S.K.; Wang, H.; Hüppi, P.S.; Volpe, J.J. Abnormal cerebral structure is present at term in premature infants. Pediatrics 2005, 115, 286-294. [CrossRef] 
49. Inder, T.E.; Wells, S.J.; Mogridge, N.B.; Spencer, C.; Volpe, J.J. Defining the nature of the cerebral abnormalities in the premature infant: A qualitative magnetic resonance imaging study. J. Pediatr. 2003, 143, 171-179. [CrossRef]

50. Parodi, A.; Malova, M.; Cardiello, V.; Raffa, S.; Re, M.; Calevo, M.G.; Severino, M.; Tortora, D.; Morana, G.; Rossi, A.; et al. Punctate white matter lesions of preterm infants: Risk factor analysis. Eur. J. Paediatr. Neurol. 2019, 23, 733-739. [CrossRef]

51. Pierson, C.R.; Al Sufiani, F. Preterm birth and cerebellar neuropathology. Semin Fetal. Neonatal. Med. 2016, 21, 305-311. [CrossRef] [PubMed]

52. Kidokoro, H.; Neil, J.J.; Inder, T.E. New MR imaging assessment tool to define brain abnormalities in very preterm infants at term. AJNR Am. J. Neuroradiol. 2013, 34, 2208-2214. [CrossRef]

53. Kidokoro, H.; Anderson, P.J.; Doyle, L.W.; Woodward, L.J.; Neil, J.J.; Inder, T.E. Brain injury and altered brain growth in preterm infants: Predictors and prognosis. Pediatrics 2014, 134, e444-e453. [CrossRef] [PubMed]

54. Tam, E.W.Y.; Chau, V.; Lavoie, R.; Chakravarty, M.M.; Guo, T.; Synnes, A.; Zwicker, J.; Grunau, R.; Miller, S.P. Neurologic Examination Findings Associated With Small Cerebellar Volumes After Prematurity. J. Child. Neurol. 2019, 34, 586-592. [CrossRef] [PubMed]

55. Tam, E.W.; Rosenbluth, G.; Rogers, E.E.; Ferriero, D.M.; Glidden, D.; Goldstein, R.B.; Glass, H.C.; Piecuch, R.E.; Barkovich, A.J. Cerebellar hemorrhage on magnetic resonance imaging in preterm newborns associated with abnormal neurologic outcome. J. Pediatr. 2011, 158, 245-250. [CrossRef] [PubMed]

56. Meijler, G.; Steggerda, S.J.; Gautier, A. Neonatal Cranial Ultrasonography; Springer: Berlin/Heidelberg, Germany, 2019.

57. Parodi, A.; Rossi, A.; Severino, M.; Morana, G.; Sannia, A.; Calevo, M.G.; Malova, M.; Ramenghi, L.A. Accuracy of ultrasound in assessing cerebellar haemorrhages in very low birthweight babies. Arch. Dis. Child. Fetal Neonatal. Ed. 2015, 100, F289-F292. [CrossRef]

58. Edwards, A.D.; Redshaw, M.E.; Kennea, N.; Rivero-Arias, O.; Gonzales-Cinca, N.; Nongena, P.; Ederies, M.; Falconer, S.; Chew, A.; Omar, O.; et al. Effect of MRI on preterm infants and their families: A randomised trial with nested diagnostic and economic evaluation. Arch. Dis. Child. Fetal Neonatal. Ed. 2018, 103, F15-F21. [CrossRef]

59. Mathur, A.M.; Neil, J.J.; McKinstry, R.C.; Inder, T.E. Transport, monitoring, and successful brain MR imaging in unsedated neonates. Pediatr. Radiol. 2008, 38, 260-264. [CrossRef]

60. O'Regan, K.; Filan, P.; Pandit, N.; Maher, M.; Fanning, N. Image quality associated with the use of an MR-compatible incubator in neonatal neuroimaging. Br. J. Radiol. 2012, 85, 363-367. [CrossRef]

61. Arthurs, O.J.; Edwards, A.; Austin, T.; Graves, M.J.; Lomas, D.J. The challenges of neonatal magnetic resonance imaging. Pediatr. Radiol. 2012, 42, 1183-1194. [CrossRef]

62. Hillenbrand, C.M.; Reykowski, A. MR Imaging of the Newborn: A technical perspective. Magn. Reson. Imaging Clin. N. Am. 2012, 20, 63-79. [CrossRef]

63. Hopkins, K.L.; Davis, P.C.; Sanders, C.L.; Churchill, L.H. Sedation for pediatric imaging studies. Neuroimaging Clin. N. Am. 1999, 9,1-10.

64. Stokowski, L.A. Ensuring safety for infants undergoing magnetic resonance imaging. Adv. Neonatal. Care 2005, 5, 14-27. [CrossRef] [PubMed]

65. Morel, B.; Antoni, G.; Teglas, J.P.; Bloch, I.; Adamsbaum, C. Neonatal brain MRI: How reliable is the radiologist's eye? Neuroradiology 2016, 58, 189-193. [CrossRef]

66. Morel, B.; Antoni, G.; Teglas, J.P.; Bloch, I.; Adamsbaum, C. Erratum to: Neonatal brain MRI: How reliable is the radiologist's eye? Neuroradiology 2016, 58, 195. [CrossRef] [PubMed]

67. Arulkumaran, S.; Arichi, T. Is there predictive value in early magnetic resonance imaging of the brain in infants born preterm? Dev. Med. Child. Neurol. 2018, 60, 116. [CrossRef] [PubMed]

68. Woodward, L.J.; Anderson, P.J.; Austin, N.C.; Howard, K.; Inder, T.E. Neonatal MRI to predict neurodevelopmental outcomes in preterm infants. N. Engl. J. Med. 2006, 355, 685-694. [CrossRef] [PubMed]

69. O'Shea, T.M.; Kuban, K.C.; Allred, E.N.; Paneth, N.; Pagano, M.; Dammann, O.; Bostic, L.; Brooklier, K.; Butler, S.; Goldstein, D.J.; et al. Neonatal cranial ultrasound lesions and developmental delays at 2 years of age among extremely low gestational age children. Pediatrics 2008, 122, e662-e669. [CrossRef] [PubMed]

70. Tudehope, D.I.; Masel, J.; Mohay, H.; O'Callaghan, M.; Burns, Y.; Rogers, Y.; Williams, G. Neonatal cranial ultrasonography as predictor of 2 year outcome of very low birthweight infants. Aust. Paediatr. J. 1989, 25, 66-71. [CrossRef]

71. Topp, M.; Uldall, P.; Greisen, G. Cerebral palsy births in eastern Denmark, 1987-90: Implications for neonatal care. Paediatr. Perinat Epidemiol. 2001, 15, 271-277. [CrossRef]

72. Hoei-Hansen, C.E.; Laursen, B.; Langhoff-Roos, J.; Rackauskaite, G.; Uldall, P. Decline in severe spastic cerebral palsy at term in Denmark 1999-2007. Eur. J. Paediatr. Neurol. 2019, 23, 94-101. [CrossRef]

73. Ancel, P.Y.; Livinec, F.; Larroque, B.; Marret, S.; Arnaud, C.; Pierrat, V.; Dehan, M.; N'Guyen, S.; Escande, B.; Burguet, A.; et al Cerebral palsy among very preterm children in relation to gestational age and neonatal ultrasound abnormalities: The EPIPAGE cohort study. Pediatrics 2006, 117, 828-835. [CrossRef]

74. Kuban, K.C.; Allred, E.N.; O'Shea, T.M.; Paneth, N.; Pagano, M.; Dammann, O.; Leviton, A.; Du Plessis, A.; Westra, S.J.; Miller, C.R.; et al. Cranial ultrasound lesions in the NICU predict cerebral palsy at age 2 years in children born at extremely low gestational age. J. Child. Neurol. 2009, 24, 63-72. [CrossRef] 
75. Cizmeci, M.N.; de Vries, L.S.; Ly, L.G.; van Haastert, I.C.; Groenendaal, F.; Kelly, E.N.; Traubici, J.; Whyte, H.E.; Leijser, L.M. Periventricular Hemorrhagic Infarction in Very Preterm Infants: Characteristic Sonographic Findings and Association with Neurodevelopmental Outcome at Age 2 Years. J. Pediatr. 2020, 217, 79-85.e71. [CrossRef] [PubMed]

76. Pierrat, V.; Marchand-Martin, L.; Arnaud, C.; Kaminski, M.; Resche-Rigon, M.; Lebeaux, C.; Bodeau-Livinec, F.; Morgan, A.S.; Goffinet, F.; Marret, S.; et al. Neurodevelopmental outcome at 2 years for preterm children born at 22 to 34 weeks' gestation in France in 2011: EPIPAGE-2 cohort study. Bmj 2017, 358, j3448. [CrossRef] [PubMed]

77. Davis, A.S.; Hintz, S.R.; Goldstein, R.F.; Ambalavanan, N.; Bann, C.M.; Stoll, B.J.; Bell, E.F.; Shankaran, S.; Laptook, A.R.; Walsh, M.C.; et al. Outcomes of extremely preterm infants following severe intracranial hemorrhage. J. Perinatol. 2014, 34, 203-208. [CrossRef]

78. Maitre, N.L.; Marshall, D.D.; Price, W.A.; Slaughter, J.C.; O'Shea, T.M.; Maxfield, C.; Goldstein, R.F. Neurodevelopmental outcome of infants with unilateral or bilateral periventricular hemorrhagic infarction. Pediatrics 2009, 124, e1153-e1160. [CrossRef]

79. Bassan, H.; Limperopoulos, C.; Visconti, K.; Mayer, D.L.; Feldman, H.A.; Avery, L.; Benson, C.B.; Stewart, J.; Ringer, S.A.; Soul, J.S.; et al. Neurodevelopmental outcome in survivors of periventricular hemorrhagic infarction. Pediatrics 2007, 120, 785-792. [CrossRef] [PubMed]

80. Soltirovska Salamon, A.; Groenendaal, F.; van Haastert, I.C.; Rademaker, K.J.; Benders, M.J.; Koopman, C.; de Vries, L.S. Neuroimaging and neurodevelopmental outcome of preterm infants with a periventricular haemorrhagic infarction located in the temporal or frontal lobe. Dev. Med. Child. Neurol. 2014, 56, 547-555. [CrossRef]

81. Fawer, C.L.; Diebold, P.; Calame, A. Periventricular leucomalacia and neurodevelopmental outcome in preterm infants. Arch. Dis. Child. 1987, 62, 30-36. [CrossRef]

82. Weiss, H.E.; Goldstein, R.B.; Piecuch, R.E. A critical review of cranial ultrasounds: Is there a closer association between intraventricular blood, white matter abnormalities or cysts, and cerebral palsy? Clin. Pediatr. (Phila) 1999, 38, 319-323. [CrossRef]

83. Al Rifai, M.T.; Al Tawil, K.I. The Neurological Outcome of Isolated PVL and Severe IVH in Preterm Infants: Is It Fair to Compare? Pediatr. Neurol. 2015, 53, 427-433. [CrossRef]

84. Resch, B.; Resch, E.; Maurer-Fellbaum, U.; Pichler-Stachl, E.; Riccabona, M.; Hofer, N.; Urlesberger, B. The whole spectrum of cystic periventricular leukomalacia of the preterm infant: Results from a large consecutive case series. Childs Nerv. Syst. 2015, 31, 1527-1532. [CrossRef] [PubMed]

85. Gotardo, J.W.; Volkmer, N.d.F.V.; Stangler, G.P.; Dornelles, A.D.; Bohrer, B.B.d.A.; Carvalho, C.G. Impact of peri-intraventricular haemorrhage and periventricular leukomalacia in the neurodevelopment of preterms: A systematic review and meta-analysis. PLoS ONE 2019, 14, e0223427. [CrossRef]

86. Banihani, R.; Church, P.T.; Luther, M.; Kiss, A.; Asztalos, E.V. Outcomes of Preterm Infants with a Periventricular Venous Infarction in the Neonatal Period. J. Pediatric Neurol. 2019, 17, 057-064. [CrossRef]

87. Leijser, L.M.; Liauw, L.; Veen, S.; de Boer, I.P.; Walther, F.J.; van Wezel-Meijler, G. Comparing brain white matter on sequential cranial ultrasound and MRI in very preterm infants. Neuroradiology 2008, 50, 799-811. [CrossRef] [PubMed]

88. De Vries, L.S.; Van Haastert, I.L.; Rademaker, K.J.; Koopman, C.; Groenendaal, F. Ultrasound abnormalities preceding cerebral palsy in high-risk preterm infants. J. Pediatr. 2004, 144, 815-820. [CrossRef]

89. Valkama, A.M.; Pääkkö, E.L.; Vainionpää, L.K.; Lanning, F.P.; Ilkko, E.A.; Koivisto, M.E. Magnetic resonance imaging at term and neuromotor outcome in preterm infants. Acta Paediatr. 2000, 89, 348-355. [CrossRef]

90. Pinto-Martin, J.A.; Riolo, S.; Cnaan, A.; Holzman, C.; Susser, M.W.; Paneth, N. Cranial ultrasound prediction of disabling and nondisabling cerebral palsy at age two in a low birth weight population. Pediatrics 1995, 95, 249-254. [PubMed]

91. Nwaesei, C.G.; Allen, A.C.; Vincer, M.J.; Brown, S.J.; Stinson, D.A.; Evans, J.R.; Byrne, J.M. Effect of timing of cerebral ultrasonography on the prediction of later neurodevelopmental outcome in high-risk preterm infants. J. Pediatr. 1988, 112, 970-975. [CrossRef]

92. Graham, M.; Levene, M.I.; Trounce, J.Q.; Rutter, N. Prediction of cerebral palsy in very low birthweight infants: Prospective ultrasound study. Lancet 1987, 2, 593-596. [CrossRef]

93. Maalouf, E.F.; Duggan, P.J.; Counsell, S.J.; Rutherford, M.A.; Cowan, F.; Azzopardi, D.; Edwards, A.D. Comparison of findings on cranial ultrasound and magnetic resonance imaging in preterm infants. Pediatrics 2001, 107, 719-727. [CrossRef]

94. Maalouf, E.F.; Duggan, P.J.; Rutherford, M.A.; Counsell, S.J.; Fletcher, A.M.; Battin, M.; Cowan, F.; Edwards, A.D. Magnetic resonance imaging of the brain in a cohort of extremely preterm infants. J. Pediatr. 1999, 135, 351-357. [CrossRef]

95. Roelants-van Rijn, A.M.; Groenendaal, F.; Beek, F.J.; Eken, P.; van Haastert, I.C.; de Vries, L.S. Parenchymal brain injury in the preterm infant: Comparison of cranial ultrasound, MRI and neurodevelopmental outcome. Neuropediatrics 2001, 32, 80-89. [CrossRef]

96. Iwata, S.; Nakamura, T.; Hizume, E.; Kihara, H.; Takashima, S.; Matsuishi, T.; Iwata, O. Qualitative brain MRI at term and cognitive outcomes at 9 years after very preterm birth. Pediatrics 2012, 129, e1138-e1147. [CrossRef]

97. Anderson, P.J.; Treyvaud, K.; Neil, J.J.; Cheong, J.L.Y.; Hunt, R.W.; Thompson, D.K.; Lee, K.J.; Doyle, L.W.; Inder, T.E. Associations of Newborn Brain Magnetic Resonance Imaging with Long-Term Neurodevelopmental Impairments in Very Preterm Children. J. Pediatr. 2017, 187, 58-65.e51. [CrossRef]

98. Jobe, A.H. MRI for preterm infants. J. Pediatr. 2009, 155, A1-A2. [CrossRef] [PubMed]

99. Eichenwald, E.C. Neuroimaging of extremely preterm infants: Perils of prediction. Pediatrics 2015, 135, e176-e177. [CrossRef] 
100. Horsch, S.; Skiöld, B.; Hallberg, B.; Nordell, B.; Nordell, A.; Mosskin, M.; Lagercrantz, H.; Adén, U.; Blennow, M. Cranial ultrasound and MRI at term age in extremely preterm infants. Arch. Dis. Child. Fetal Neonatal. Ed. 2010, 95, F310-F314. [CrossRef]

101. Arulkumaran, S.; Tusor, N.; Chew, A.; Falconer, S.; Kennea, N.; Nongena, P.; Hajnal, J.V.; Counsell, S.J.; Rutherford, M.A.; Edwards, A.D. MRI Findings at Term-Corrected Age and Neurodevelopmental Outcomes in a Large Cohort of Very Preterm Infants. AJNR Am. J. Neuroradiol. 2020, 41, 1509-1516. [CrossRef]

102. Parikh, N.A.; He, L.; Priyanka Illapani, V.S.; Altaye, M.; Folger, A.T.; Yeates, K.O. Objectively Diagnosed Diffuse White Matter Abnormality at Term Is an Independent Predictor of Cognitive and Language Outcomes in Infants Born Very Preterm. J. Pediatr. 2020, 220, 56-63. [CrossRef]

103. Slaughter, L.A.; Bonfante-Mejia, E.; Hintz, S.R.; Dvorchik, I.; Parikh, N.A. Early Conventional MRI for Prediction of Neurodevelopmental Impairment in Extremely-Low-Birth-Weight Infants. Neonatology 2016, 110, 47-54. [CrossRef]

104. Spittle, A.J.; Cheong, J.; Doyle, L.W.; Roberts, G.; Lee, K.J.; Lim, J.; Hunt, R.W.; Inder, T.E.; Anderson, P.J. Neonatal white matter abnormality predicts childhood motor impairment in very preterm children. Dev. Med. Child. Neurol. 2011, 53, 1000-1006. [CrossRef]

105. George, J.M.; Pannek, K.; Rose, S.E.; Ware, R.S.; Colditz, P.B.; Boyd, R.N. Diagnostic accuracy of early magnetic resonance imaging to determine motor outcomes in infants born preterm: A systematic review and meta-analysis. Dev. Med. Child. Neurol. 2018, 60, 134-146. [CrossRef] [PubMed]

106. Van't Hooft, J.; van der Lee, J.H.; Opmeer, B.C.; Aarnoudse-Moens, C.S.; Leenders, A.G.; Mol, B.W.; de Haan, T.R. Predicting developmental outcomes in premature infants by term equivalent MRI: Systematic review and meta-analysis. Syst. Rev. 2015, 4, 71. [CrossRef]

107. Limperopoulos, C.; Bassan, H.; Gauvreau, K.; Robertson, R.L., Jr.; Sullivan, N.R.; Benson, C.B.; Avery, L.; Stewart, J.; Soul, J.S.; Ringer, S.A.; et al. Does cerebellar injury in premature infants contribute to the high prevalence of long-term cognitive, learning, and behavioral disability in survivors? Pediatrics 2007, 120, 584-593. [CrossRef]

108. Dyet, L.E.; Kennea, N.; Counsell, S.J.; Maalouf, E.F.; Ajayi-Obe, M.; Duggan, P.J.; Harrison, M.; Allsop, J.M.; Hajnal, J.; Herlihy, A.H.; et al. Natural history of brain lesions in extremely preterm infants studied with serial magnetic resonance imaging from birth and neurodevelopmental assessment. Pediatrics 2006, 118, 536-548. [CrossRef]

109. Hortensius, L.M.; Dijkshoorn, A.B.C.; Ecury-Goossen, G.M.; Steggerda, S.J.; Hoebeek, F.E.; Benders, M.; Dudink, J. Neurodevelopmental Consequences of Preterm Isolated Cerebellar Hemorrhage: A Systematic Review. Pediatrics 2018, 142. [CrossRef]

110. Zayek, M.M.; Benjamin, J.T.; Maertens, P.; Trimm, R.F.; Lal, C.V.; Eyal, F.G. Cerebellar hemorrhage: A major morbidity in extremely preterm infants. J. Perinatol. 2012, 32, 699-704. [CrossRef] [PubMed]

111. Omizzolo, C.; Scratch, S.E.; Stargatt, R.; Kidokoro, H.; Thompson, D.K.; Lee, K.J.; Cheong, J.; Neil, J.; Inder, T.E.; Doyle, L.W.; et al. Neonatal brain abnormalities and memory and learning outcomes at 7 years in children born very preterm. Memory 2014, 22, 605-615. [CrossRef]

112. Omizzolo, C.; Thompson, D.K.; Scratch, S.E.; Stargatt, R.; Lee, K.J.; Cheong, J.; Roberts, G.; Doyle, L.W.; Anderson, P.J. Hippocampal volume and memory and learning outcomes at 7 years in children born very preterm. J. Int. Neuropsychol. Soc. 2013, 19, 1065-1075. [CrossRef]

113. Murray, A.L.; Scratch, S.E.; Thompson, D.K.; Inder, T.E.; Doyle, L.W.; Anderson, J.F.; Anderson, P.J. Neonatal brain pathology predicts adverse attention and processing speed outcomes in very preterm and/or very low birth weight children. Neuropsychology 2014, 28, 552-562. [CrossRef] [PubMed]

114. Wang, S.S.; Kloth, A.D.; Badura, A. The cerebellum, sensitive periods, and autism. Neuron 2014, 83, 518-532. [CrossRef] [PubMed]

115. Schmahmann, J.D.; Sherman, J.C. The cerebellar cognitive affective syndrome. Brain 1998, 121, 561-579. [CrossRef]

116. Adamaszek, M.; D’Agata, F.; Ferrucci, R.; Habas, C.; Keulen, S.; Kirkby, K.C.; Leggio, M.; Mariën, P.; Molinari, M.; Moulton, E.; et al. Consensus Paper: Cerebellum and Emotion. Cerebellum 2017, 16, 552-576. [CrossRef] [PubMed]

117. Ibrahim, J.; Mir, I.; Chalak, L. Brain imaging in preterm infants $<32$ weeks gestation: A clinical review and algorithm for the use of cranial ultrasound and qualitative brain MRI. Pediatr. Res. 2018, 84, 799-806. [CrossRef] [PubMed]

118. Zhang, X.H.; Qiu, S.J.; Chen, W.J.; Gao, X.R.; Li, Y.; Cao, J.; Zhang, J.J. Predictive Value of Cranial Ultrasound for Neurodevelopmental Outcomes of Very Preterm Infants with Brain Injury. Chin. Med. J. (Engl.) 2018, 131, 920-926. [CrossRef] [PubMed]

119. Hou, W.; Tang, P.H.; Agarwal, P. The most useful cranial ultrasound predictor of neurodevelopmental outcome at 2 years for preterm infants. Clin. Radiol. 2020, 75, 278-286. [CrossRef] [PubMed]

120. Munck, P.; Haataja, L.; Maunu, J.; Parkkola, R.; Rikalainen, H.; Lapinleimu, H.; Lehtonen, L. Cognitive outcome at 2 years of age in Finnish infants with very low birth weight born between 2001 and 2006. Acta Paediatr. 2010, 99, 359-366. [CrossRef]

121. Laptook, A.R.; O'Shea, T.M.; Shankaran, S.; Bhaskar, B. Adverse neurodevelopmental outcomes among extremely low birth weight infants with a normal head ultrasound: Prevalence and antecedents. Pediatrics 2005, 115, 673-680. [CrossRef]

122. Adams-Chapman, I.; Hansen, N.I.; Stoll, B.J.; Higgins, R. Neurodevelopmental outcome of extremely low birth weight infants with posthemorrhagic hydrocephalus requiring shunt insertion. Pediatrics 2008, 121, e1167-e1177. [CrossRef]

123. Patra, K.; Wilson-Costello, D.; Taylor, H.G.; Mercuri-Minich, N.; Hack, M. Grades I-II intraventricular hemorrhage in extremely low birth weight infants: Effects on neurodevelopment. J. Pediatr. 2006, 149, 169-173. [CrossRef] [PubMed]

124. Sherlock, R.L.; Anderson, P.J.; Doyle, L.W. Neurodevelopmental sequelae of intraventricular haemorrhage at 8 years of age in a regional cohort of ELBW/very preterm infants. Early Hum. Dev. 2005, 81, 909-916. [CrossRef] 
125. Whitaker, A.H.; Feldman, J.F.; Van Rossem, R.; Schonfeld, I.S.; Pinto-Martin, J.A.; Torre, C.; Blumenthal, S.R.; Paneth, N.S. Neonatal cranial ultrasound abnormalities in low birth weight infants: Relation to cognitive outcomes at six years of age. Pediatrics 1996, 98, 719-729. [CrossRef]

126. Anderson, P.J.; Cheong, J.L.; Thompson, D.K. The predictive validity of neonatal MRI for neurodevelopmental outcome in very preterm children. Semin Perinatol. 2015, 39, 147-158. [CrossRef]

127. Roze, E.; Van Braeckel, K.N.; van der Veere, C.N.; Maathuis, C.G.; Martijn, A.; Bos, A.F. Functional outcome at school age of preterm infants with periventricular hemorrhagic infarction. Pediatrics 2009, 123, 1493-1500. [CrossRef] [PubMed]

128. Levene, M.I. Is neonatal cerebral ultrasound just for the voyeur? Arch. Dis. Child. 1988, 63, 1-2. [CrossRef] [PubMed]

129. Bauer, A.; Knapp, M.; Parsonage, M. Lifetime costs of perinatal anxiety and depression. J. Affect Disord. 2016, 192, 83-90. [CrossRef] [PubMed]

130. Zelkowitz, P.; Na, S.; Wang, T.; Bardin, C.; Papageorgiou, A. Early maternal anxiety predicts cognitive and behavioural outcomes of VLBW children at 24 months corrected age. Acta Paediatr. 2011, 100, 700-704. [CrossRef] [PubMed]

131. Peeples, E.S. Utilizing Neonatal Brain Imaging to Predict Neurodevelopmental Outcomes. In Follow-Up for NICU Graduates: Promoting Positive Developmental and Behavioral Outcomes for At-Risk Infants; Needelman, H., Jackson, B.J., Eds.; Springer International Publishing: Cham, Switzerland, 2018; pp. 59-88. [CrossRef]

132. Nordhov, S.M.; Rønning, J.A.; Dahl, L.B.; Ulvund, S.E.; Tunby, J.; Kaaresen, P.I. Early intervention improves cognitive outcomes for preterm infants: Randomized controlled trial. Pediatrics 2010, 126, e1088-e1094. [CrossRef]

133. Spittle, A.J.; Orton, J.; Doyle, L.W.; Boyd, R. Early developmental intervention programs post hospital discharge to prevent motor and cognitive impairments in preterm infants. Cochrane Database Syst. Rev. 2007, Cd005495. [CrossRef]

134. Janvier, A.; Barrington, K. Trying to predict the future of ex-preterm infants: Who benefits from a brain MRI at term? Acta Paediatr. 2012, 101, 1016-1017. [CrossRef]

135. Nongena, P.; Ederies, A.; Azzopardi, D.V.; Edwards, A.D. Confidence in the prediction of neurodevelopmental outcome by cranial ultrasound and MRI in preterm infants. Arch. Dis. Child. Fetal Neonatal. Ed. 2010, 95, F388-F390. [CrossRef]

136. Pearce, R.; Baardsnes, J. Term MRI for small preterm babies: Do parents really want to know and why has nobody asked them? Acta Paediatr. 2012, 101, 1013-1015. [CrossRef]

137. Harvey, M.E.; Nongena, P.; Gonzalez-Cinca, N.; Edwards, A.D.; Redshaw, M.E. Parents' experiences of information and communication in the neonatal unit about brain imaging and neurological prognosis: A qualitative study. Acta Paediatr. 2013, 102, 360-365. [CrossRef] [PubMed]

138. Sudia-Robinson, T.M.; Freeman, S.B. Communication patterns and decision making among parents and health care providers in the neonatal intensive care unit: A case study. Heart Lung. 2000, 29, 143-148. [CrossRef]

139. Fowlie, P.W.; Jackson, A. Communicating with parents on the neonatal unit. Bmj 2007, 334, 1. [CrossRef] [PubMed]

140. Buchiboyina, A.; Yip, C.S.A.; Madhala, S.; Patole, S. Incidental Findings on Brain Magnetic Resonance Imaging in Preterm Infants. Neonatology 2019, 115, 1-4. [CrossRef] [PubMed]

141. Malova, M.; Rossi, A.; Severino, M.; Parodi, A.; Morana, G.; Sannia, A.; Cama, A.; Ramenghi, L.A. Incidental findings on routine brain MRI scans in preterm infants. Arch. Dis. Child. Fetal Neonatal. Ed. 2017, 102, F73-F78. [CrossRef]

142. Morris, Z.; Whiteley, W.N.; Longstreth, W.T., Jr.; Weber, F.; Lee, Y.C.; Tsushima, Y.; Alphs, H.; Ladd, S.C.; Warlow, C.; Wardlaw, J.M.; et al. Incidental findings on brain magnetic resonance imaging: Systematic review and meta-analysis. BMJ 2009, 339, b3016. [CrossRef]

143. Kumra, S.; Ashtari, M.; Anderson, B.; Cervellione, K.L.; Kan, L.I. Ethical and practical considerations in the management of incidental findings in pediatric MRI studies. J. Am. Acad. Child. Adolesc Psychiatry 2006, 45, 1000-1006. [CrossRef] [PubMed]

144. Dangouloff-Ros, V.; Roux, C.J.; Boulouis, G.; Levy, R.; Nicolas, N.; Lozach, C.; Grevent, D.; Brunelle, F.; Boddaert, N.; Naggara, O. Incidental Brain MRI Findings in Children: A Systematic Review and Meta-Analysis. AJNR Am. J. Neuroradiol. 2019, 40, 1818-1823. [CrossRef]

145. Miller, S.; Ferriero, D.; Barkovich, A.J.; Silverstein, F. Practice parameter: Neuroimaging of the neonate: Report of the Quality Standards Subcommittee of the American Academy of Neurology and the Practice Committee of the Child Neurology Society. Neurology 2002, 59, 1663. [CrossRef]

146. Mirmiran, M.; Barnes, P.D.; Keller, K.; Constantinou, J.C.; Fleisher, B.E.; Hintz, S.R.; Ariagno, R.L. Neonatal brain magnetic resonance imaging before discharge is better than serial cranial ultrasound in predicting cerebral palsy in very low birth weight preterm infants. Pediatrics 2004, 114, 992-998. [CrossRef]

147. Neubauer, V.; Griesmaier, E.; Baumgartner, K.; Mallouhi, A.; Keller, M.; Kiechl-Kohlendorfer, U. Feasibility of cerebral MRI in non-sedated preterm-born infants at term-equivalent age: Report of a single centre. Acta Paediatr. 2011, 100, 1544-1547. [CrossRef]

148. Smyser, C.D.; Kidokoro, H.; Inder, T.E. Magnetic resonance imaging of the brain at term equivalent age in extremely premature neonates: To scan or not to scan? J. Paediatr. Child. Health 2012, 48, 794-800. [CrossRef] [PubMed]

149. Ho, T.; Dukhovny, D.; Zupancic, J.A.; Goldmann, D.A.; Horbar, J.D.; Pursley, D.M. Choosing Wisely in Newborn Medicine: Five Opportunities to Increase Value. Pediatrics 2015, 136, e482-e489. [CrossRef] [PubMed]

150. de Amorim e Silva, C.J.; Mackenzie, A.; Hallowell, L.M.; Stewart, S.E.; Ditchfield, M.R. Practice MRI: Reducing the need for sedation and general anaesthesia in children undergoing MRI. Australas Radiol. 2006, 50, 319-323. [CrossRef] [PubMed]

151. Linsell, L.; Malouf, R.; Morris, J.; Kurinczuk, J.J.; Marlow, N. Prognostic Factors for Poor Cognitive Development in Children Born Very Preterm or With Very Low Birth Weight: A Systematic Review. JAMA Pediatr. 2015, 169, 1162-1172. [CrossRef] 
152. Neubauer, V.; Junker, D.; Griesmaier, E.; Schocke, M.; Kiechl-Kohlendorfer, U. Bronchopulmonary dysplasia is associated with delayed structural brain maturation in preterm infants. Neonatology 2015, 107, 179-184. [CrossRef]

153. Spittle, A.J.; Boyd, R.N.; Inder, T.E.; Doyle, L.W. Predicting motor development in very preterm infants at 12 months' corrected age: The role of qualitative magnetic resonance imaging and general movements assessments. Pediatrics 2009, 123, 512-517. [CrossRef]

154. Pires, C.D.S.; Marba, S.T.M.; Caldas, J.P.S.; Stopiglia, M.C.S. PREDICTIVE VALUE OF THE GENERAL MOVEMENTS ASSESSMENT IN PRETERM INFANTS: A META-ANALYSIS. Rev. Paul. Pediatr. 2020, 38, e2018286. [CrossRef]

155. Spittle, A.J.; Brown, N.C.; Doyle, L.W.; Boyd, R.N.; Hunt, R.W.; Bear, M.; Inder, T.E. Quality of general movements is related to white matter pathology in very preterm infants. Pediatrics 2008, 121, e1184-e1189. [CrossRef]

156. Herzmann, C.; Zubiaurre-Elorza, L.; Wild, C.J.; Linke, A.C.; Han, V.K.; Lee, D.S.C.; Cusack, R. Using Functional Magnetic Resonance Imaging to Detect Preserved Function in a Preterm Infant with Brain Injury. J. Pediatr. 2017, 189, 213-217.e211. [CrossRef]

157. Duncan, A.F.; Bann, C.M.; Dempsey, A.G.; Adams-Chapman, I.; Heyne, R.; Hintz, S.R. Neuroimaging and Bayley-III correlates of early hand function in extremely preterm children. J. Perinatol. 2019, 39, 488-496. [CrossRef] [PubMed]

158. Romeo, D.M.; Cowan, F.M.; Haataja, L.; Ricci, D.; Pede, E.; Gallini, F.; Cota, F.; Brogna, C.; Vento, G.; Romeo, M.G.; et al. Hammersmith Infant Neurological Examination for infants born preterm: Predicting outcomes other than cerebral palsy. Dev. Med. Child. Neurol. 2020. [CrossRef]

159. Novak, I.; Morgan, C. Are Structural Magnetic Resonance Imaging and General Movements Assessment Sufficient for Early, Accurate Diagnosis of Cerebral Palsy?-Reply. JAMA Pediatr. 2018, 172, 199. [CrossRef]

160. Parikh, N.A. Are Structural Magnetic Resonance Imaging and General Movements Assessment Sufficient for Early, Accurate Diagnosis of Cerebral Palsy? JAMA Pediatr. 2018, 172, 198-199. [CrossRef] [PubMed]

161. Constantinou, J.C.; Adamson-Macedo, E.N.; Mirmiran, M.; Fleisher, B.E. Movement, imaging and neurobehavioral assessment as predictors of cerebral palsy in preterm infants. J. Perinatol. 2007, 27, 225-229. [CrossRef] [PubMed]

162. Herskind, A.; Greisen, G.; Nielsen, J.B. Early identification and intervention in cerebral palsy. Dev. Med. Child. Neurol. 2015, 57, 29-36. [CrossRef]

163. Spittle, A.J.; Morgan, C.; Olsen, J.E.; Novak, I.; Cheong, J.L.Y. Early Diagnosis and Treatment of Cerebral Palsy in Children with a History of Preterm Birth. Clin. Perinatol. 2018, 45, 409-420. [CrossRef]

164. Morgan, C.; Romeo, D.M.; Chorna, O.; Novak, I.; Galea, C.; Del Secco, S.; Guzzetta, A. The Pooled Diagnostic Accuracy of Neuroimaging, General Movements, and Neurological Examination for Diagnosing Cerebral Palsy Early in High-Risk Infants: A Case Control Study. J. Clin. Med. 2019, 8, 1879. [CrossRef]

165. Morgan, C.; Novak, I.; Dale, R.C.; Guzzetta, A.; Badawi, N. Single blind randomised controlled trial of GAME (Goals-ActivityMotor Enrichment) in infants at high risk of cerebral palsy. Res. Dev. Disabil. 2016, 55, 256-267. [CrossRef]

166. Eliasson, A.C.; Nordstrand, L.; Ek, L.; Lennartsson, F.; Sjöstrand, L.; Tedroff, K.; Krumlinde-Sundholm, L. The effectiveness of Baby-CIMT in infants younger than 12 months with clinical signs of unilateral-cerebral palsy; an explorative study with randomized design. Res. Dev. Disabil. 2018, 72, 191-201. [CrossRef]

167. Hägglund, G.; Alriksson-Schmidt, A.; Lauge-Pedersen, H.; Rodby-Bousquet, E.; Wagner, P.; Westbom, L. Prevention of dislocation of the hip in children with cerebral palsy: 20-year results of a population-based prevention programme. Bone Joint J. 2014, 96-b, 1546-1552. [CrossRef]

168. Spittle, A.J.; Barton, S.; Treyvaud, K.; Molloy, C.S.; Doyle, L.W.; Anderson, P.J. School-Age Outcomes of Early Intervention for Preterm Infants and Their Parents: A Randomized Trial. Pediatrics 2016, 138. [CrossRef]

169. Bosanquet, M.; Copeland, L.; Ware, R.; Boyd, R. A systematic review of tests to predict cerebral palsy in young children. Dev. Med. Child. Neurol. 2013, 55, 418-426. [CrossRef] [PubMed]

170. Novak, I.; Morgan, C.; Adde, L.; Blackman, J.; Boyd, R.N.; Brunstrom-Hernandez, J.; Cioni, G.; Damiano, D.; Darrah, J.; Eliasson, A.C.; et al. Early, Accurate Diagnosis and Early Intervention in Cerebral Palsy: Advances in Diagnosis and Treatment. JAMA Pediatr. 2017, 171, 897-907. [CrossRef] [PubMed]

171. Caesar, R.; Colditz, P.B.; Cioni, G.; Boyd, R.N. Clinical tools used in young infants born very preterm to predict motor and cognitive delay (not cerebral palsy): A systematic review. Dev. Med. Child. Neurol. 2020. [CrossRef] [PubMed]

172. Young, J.M.; Morgan, B.R.; Powell, T.L.; Moore, A.M.; Whyte, H.E.; Smith, M.L.; Taylor, M.J. Associations of Perinatal Clinical and Magnetic Resonance Imaging Measures with Developmental Outcomes in Children Born Very Preterm. J. Pediatr. 2016, 170, 90-96. [CrossRef] [PubMed]

173. Kanel, D.; Counsell, S.J.; Nosarti, C. Advances in functional and diffusion neuroimaging research into the long-term consequences of very preterm birth. J. Perinatol. 2020. [CrossRef] 